\title{
Remaking Science Teaching: Border Crossing Between Home and School
}

\author{
Sumer Seiki, Daniela Domínguez, and Jolynn Asato
}

\begin{abstract}
In this case study, we explore ways to prepare preservice teachers to translate theory into practice and make science curriculum accessible through familial curriculum. Using her "Family Science Lesson Planning" assignment sequence, Sumer taught preservice teachers the theory of transformative curriculum making (Seiki, 2016), and guided them to recognize, articulate, and translate their own familial curriculum into science lessons. As a result, the three participant preservice teachers' own histories and familial knowledge were repositioned and valued alongside science. Our findings show how to use science curriculum and instruction to border cross between home and school, thereby making science more accessible.
\end{abstract}

\section{Background}

Responding to education researchers' call to make science relatable through curriculum and pedagogy for diverse students (Lee \& Fradd, 1998; Bang et al., 2012), we explore issues of unequal distribution and access to the tools needed to thrive in science for both diverse students and their teachers (Education Trust-West, 2015). California's segregated schools have limited science curriculum, resources, and professional development for their teachers, directly affecting students (Education Trust-West, 2015). The National Science Teaching Association suggests curriculum affects students' achievement, confidence, and perceptions of science (Miller et al., 2015). This lack of access, resources, and professional development can have grave consequences for students.

Science curriculum is often abstract and requires students to learn scientific terms and memorize principles that have had little relevance in their lives (Oakes et al., 2013), and students often struggle to connect home and school, since these worlds linguistically, epistemologically, and ontologically do not align (Clegg \& Kolodner, 2014; Tsurusaki et al., 2013). This focus on facts and memorization reflects a teaching disposition that favors assimilation of diverse students to "mainstream ways of communicating and knowing" (Santau \& Ritter, 2013, p. 261), the effects of which are harmful in that they devalue students' cultural knowledge. Since curriculum is shaped through larger historical, sociopolitical, and economic forces (Freire, 1970, 1973), the clear shortcomings in memorization-based and assimilationist science curricula (Aikenhead \& Elliot, 2010) are not surprising. In turn, it is imperative to provide science support to teachers entering into this context.

Building on this earlier work, researchers are now exploring ways for preservice teachers to learn how to teach science in culturally responsive and accessible ways (McLaughlin \& Calabrese Barton, 2013). 
Part of the difficulty beginning teachers have when using home and community cultural resources to instruct students in science, is the cultural divide between home and school, which is characterized as a border (Aikenhead \& Elliot, 2010). In this article, we explore a way to cross the border between home and science knowledge through transformative curriculum making (Seiki, 2016), which is a tool in science education that helps preservice teachers border cross by using their personal assets to learn and teach science, and create more equitable and inclusive learning spaces within hegemonic institutions (Seiki, 2016, 2017). Our research puzzle centers the question, "In what ways do preservice teachers learn to recognize, articulate, and translate their own familial curriculum to create elementary science lesson plans for diverse urban students through a transformative curriculum-making assignment sequence?"

\section{Border Crossing}

Sumer purposefully situated her classroom curriculum within the call to design accessible science curriculum for teachers and their students. She knew science curriculum and pedagogy often excluded women and marginalized communities through "entrenched, usually hidden, boundaries that tend to control the borders of acceptable meanings and meaning-making practices" (Bang et al., 2012, p. 303). Additionally, race and racism shape the epistemological debate between those whose knowledge counts, and those for whom it is discounted (Yosso, 2005, p. 70). Thus, due to the ways bias acts like a gatekeeper of valued knowledge, Sumer was spurred to investigate accessible curriculum.

She was inspired by Aikenhead and Elliott's (2010) First Nations student study in Canada, which found that in order for students to be successful, they needed to learn-unfortunately, without teacher assistance- to cross a cultural border between their own cultural knowledge and the cultural knowledge of academic school science. Since many students were unable to do this, they felt alienated by the foreign language of science, not able to take up an identity as a scientist. To create a more fluid border crossing, Aikenhead (2000) suggests that science teachers must: (a) make border crossings explicit for students, (b) facilitate border crossings, and (c) substantiate the validity of students' personally and culturally constructed ways of knowing (p. 228). To bridge these opposing paradigms within their classrooms, Sumer incorporated Aikenhead and Elliott's three suggestions into her Family Science Lesson Planning assignment and incorporated familial curriculum to further strengthen the science-learning access.

\section{Family Curriculum Making in Science: Revaluing Science Instruction in the Home}

"Familial curriculum making" is a concept that emerged from narrative inquiry, hence it is grounded in the relational and is conceptualized narratively; it is a dynamic construction of a life along an evolving plotline (Clandinin et al., 2011; Huber et al., 2011). Familial curriculum making is inclusive of personal, familial, community, and cultural knowledge, stories, and emotions, which are cultivated generationally and passed in relationships. Familial curriculum making is distinct from the place of school curriculum making (Clandinin et al., 2011; Huber et al., 2011), and is important to both classroom and school 
curriculum teaching (Huber et al., 2011). Incorporating familial curriculum benefits student education outcomes, and offers teachers and teacher educators a social-justice-based pedagogical technique in cross-cultural contexts (Houle, 2015; Lessard, 2015).

Moll and colleagues (1992) suggest that teachers learn to identify students' funds of knowledge"the historically accumulated and culturally developed bodies of knowledge and skills essential for household or individual functioning and well-being" (p. 133) - by observing familial and community activities and analyzing social and labor histories in households, in order to "reveal the accumulated bodies and embodied knowledge of households" (p. 133). Moll et al. suggest removing barriers between home and school and inviting teachers to enter into the homes of students to facilitate higher-order content learning. Though this type of teaching is highly effective, researchers and practitioners note it is not easy. Sumer used Moll et al.'s concept, but instead of teachers entering into the homes of students, Sumer proposed something new. By suggesting her preservice teachers invite students into the preservice teachers' homes through teaching their science lesson, Sumer teaches preservice teachers to value family curriculum through sharing from their own funds of knowledge.

Yosso (2005) added to research on familial knowledge by providing insight into passing ancestral knowledge through community cultural wealth. Using Bourdieu and Passeron's (1977) concept of social capital, she explained that marginalized community assets can be categorized into aspirational, familial, social, cultural, linguistic, resistant, and navigational capital-each of these capitals shows the depth of knowledge and complexity gained outside of school. We suggest that although Moll et al.'s (1992) ethnography and Yosso's critical race theory research are from different research paradigms, both contribute to the conceptual understanding of familial curriculum.

\section{Transformative Curriculum Making}

Incorporating familial curriculum is a central part of this process of transformative curriculum making. Seiki (2016) describes transformative curriculum making as constructing curriculum that counters hegemonic learning spaces within science content. Transformative curriculum making creates a spectrum of diverse curriculum, pulling from the students' and teachers' familial curriculum, and diverse teaching epistemologies.

By bringing together transformative curriculum making and familial curriculum, Sumer created an assignment entitled Family Science Lesson Planning to prepare preservice teachers to address known science access inequities for themselves and their students. Through this four-assignment sequence, she scaffolded preservice teachers in the transformative curriculum making process of recognizing, articulating, and translating their familial curriculum, a process that confronted the epistemological divide between home and school. Aware of the segregated elementary schools her preservice teachers often enter, her objective was to teach them how to make curriculum that considered the lived experiences of their diverse students as well as to meet the current California science instruction time constraints, an average of 27 minutes per week (Education Trust-West, 2015). By the end of this 
sequence, students possessed the skill of making short, culturally relevant science curriculum, ideal for the urban California context.

Sumer's goal with this study was to explore ways to make science relevant for both preservice teachers and their students, creating conditions for preservice teachers to identify and access their own and their students' familial curriculum when teaching science. Accessing a teacher's familial curriculum may help educators better identify and utilize their students' own familial curriculum in learning science, as well as teach students that they have a right to their own histories within the classroom. While research has focused on teachers learning their students' funds of knowledge first, we uniquely propose beginning with teachers first focusing on accessing their own familial curriculum in order to apply it to their students.

\section{Method}

This case study is situated in Sumer's Curriculum and Instruction of Elementary Science Methods Course, and was approved by the Institutional Review Board for the Protection of Human Subjects at an urban west coast university. The seven-week course had 14 preservice teachers enrolled, and met once a week for three hours and forty minutes. This was the first graduate course in which preservice teachers learned to teach elementary school science content; none of the students were science majors and had limited science background knowledge.

Case studies use a diverse data set including interview, classroom observations, and classroom artifacts revealing the implicit and hidden pedagogical implications of using and enacting science curriculum (Marco-Bujosa et al., 2017). Like Miller and colleagues' (2015) case study format for their National Association of Science Teachers study, Sumer presented individual classroom case data through narrative vignettes and classroom assignment artifacts collected from classroom field note reflections.

Classroom observations were a significant data source that Sumer captured in field notes. Further information was gathered to confirm the findings, including interviews, classroom lesson plans, and assignment artifacts. Assignment artifacts also served to further confirm the primary data source of field notes and reveal participants' internal thoughts and experiences. Additionally, each of the interview participants reviewed and approved Sumer's narrative vignettes included in this article, which served as a participant check.

The three interview participants in this study took this course together in their second year of an elementary teacher credential program. Participants were selected through criterion sampling, which selects participants, "that meet some predetermined criterion of importance" (Patton, 2002, p. 238). Eligibility criteria included individuals who completed the course, participated in the assignment sequence, and were at least age 18 and older. To ensure data confidentiality, pseudonyms were used. Participants were students of color or multiracial: Kara was a mixed-race Pacific Islander student, Elaine was an Asian American student, and Diego was a mixed-race Latinx student. 
Prior to starting the individual semi-structured interviews, Sumer presented the interview questions to the participants and obtained permission to audio-record the interview. During the interview, participants shared their experience with the four-assignment sequence. Participants' interview transcripts and class assignment artifacts were then analyzed. Inquiring in this way allowed Sumer to explore her preservice teachers' transformative curriculum-making process with the four-sequence course assignment. Danny and Jolynn reviewed the research methods, data analysis, and theoretical frame and provided insights which, in turn, informed the conclusions articulated in this article.

\section{Family Science Lesson-Planning Sequence}

To prepare students to complete the course sequence, Sumer selected and had students complete readings on: inequitable science access (Education Trust West, 2015), Western science and indigenous epistemological divide (Bang et al., 2012), and the benefits of incorporating familial knowledge in science instruction (Moll et al., 1992; Rosiek \& Clandinin, 2015; Yosso, 2005), as described in the literature review. After finishing the readings, students discussed the rationale for Family Science Lesson Planning.

To assess student learning, Sumer examined students' ability to complete each of the four assignments within the sequence. The course assignment sequence required preservice teachers to: (a) recognize science familial curriculum in their own lives, (b) draw and share a memory alongside a science concept, (c) translate that memory into a 10-minute science lesson plan for culturally diverse elementary students, and (d) teach the planned lesson in relatable, culturally relevant, and scientifically accurate ways. She analyzed each classroom observation alongside interview transcripts.

\section{Case Study Data analysis}

We used a narrative inquiry lens to understand and unravel the complexities of human experiences within our case study data (Clandinin \& Connelly, 1995). Each classroom narrative vignette existed within a three-dimensional space: temporal, social, and place-based. Investigating these dimensions allowed us to examine the interplay between these dimensions and the preservice teachers' familial curriculum. It was a process of exploring intersecting networks of life threads, interwoven in a particular space and time. Narrative inquiry informed our analysis process, helping us move inward, outward, backward, and forward within a three-dimensional narrative space captured in the vignettes (Clandinin \& Connelly, 2000).

We analyzed the four-assignment sequence in a narrative style. We presented the larger conceptual themes that were identified through field notes, interviews, and artifacts (data). Each piece of data is interwoven with analysis and shows the evolution of students' learning through the assignment sequence. 


\section{Findings}

Our findings are organized into themed sections. We report on the preservice teachers' engagement with making the border explicit (Aikenhead \& Elliot, 2010), and progress to recount their attempts to border cross. The results illuminate a spectrum of learning as the preservice teachers navigated the tensions of border crossing between home and science curriculum.

\section{Making the Border Explicit}

The concept of making science borders visible became apparent from the data collected through Assignments 1 and 2. In these assignments, which we present in sequential order below, Sumer prepared preservice teachers to border cross by first having them see their homes as a site of science learning. She facilitated making this visible by having preservice teachers discuss the science practices that existed within their home life. This was a difficult but important process; students struggled to reduce the borders between home and school.

We looked at possibilities for science in Sumer's classroom observation of Assignment 1, captured in her vignette below. Interview quotes also reveal the preservice teachers' learning process. The focus of this section is to understand the ways Sumer's preservice teachers recognized their familial curriculum, thus making the border explicit.

Sumer projected onto a screen the question, "In what ways did you learn science at home?" and instructed them to discuss this in pairs or table groups. At first, students hesitated to begin talking. Some looked confused. Sumer waited for students to process and begin their conversations before circulating. When Sumer visited groups to help facilitate, they asked her questions like, "Is this ok to talk about, is this science?"

This vignette illustrated the preservice teachers' learning process, in which they wrestled with accessing familial curriculum making in science; they struggled to see home as a place of science learning and teaching. In engaging with this activity, preservice teachers learned how hard it is to recognize and connect home and science: they personally experienced the distance that science hegemony maintains.

In order to understand the specific difficulty preservice teachers had in recalling family science memories, Sumer conducted individual interviews. Elaine and Kara both provided insights about their difficulties and process of making connections. Elaine said:

At first, I thought, I can't think of anything. I can't remember specifically any science from a book, or a science project from a book, or anything. I thought about it for a while, and I just thought about what I did in my childhood. I spent a lot of time with my parents, and ... a lot of my childhood was helping ... cook and garden ...then I tried to think about what science came from that. I remember as a kid, I remember us frying chicken, frying fish, frying eggrolls. I remember being taught that every time before dinner, my mom and dad would have us help prep. And then I remember specifically my mom saying to do this right, to cook the food right, you need to put this amount of egg rolls into the oil because it's not going to cook right. 
In her quote above, Elaine recognized how hard it was to connect home and science. She struggled to find what "science" her family taught her. In fact, she revealed that her frame of reference was anchored in a traditional science textbook. She used her recollection of science textbook concepts to evaluate which of her home experiences would fit science instruction in the home. Her valuation of school science content knowledge in textbooks is indicative of the larger struggle of valuing Western knowledge over familial knowledge (Bang et al., 2012). The activity enabled her to make the border between home and school visible. Kara explained:

I remember really feeling like in science you can't make mistakes. There's all these rules and it's like right and wrong. So it's hard to fit your own family knowledge into that because it seems like science is this distant thing set in stone and you kind of fit into your life rather than fit your life into it. I think it was also kind of hard for me because everything I was taught [in science] didn't have familial knowledge in it so that was really separate for me. It was two very separate things.

As Kara said, it was "separate," indicative of the epistemological divide that separates school and home science curriculum (Aikenhead \& Elliot, 2010). Identifying science content learned from their families, the students started to unearth the value of their family science. As students engaged with Assignment 1, they did not see their homes as potential sites of science learning. As they talked and thought about the question, all of the preservice teachers made the border between home and school visible.

\section{Unmasking the Border Between Home and School}

After Assignment 1, the preservice teachers immediately began Assignment 2, in which they moved from uncovering their family science and began to articulate the science concepts they learned from their families. This articulation served to unmask the border in that students could see how family science was informed by science concepts, and in fact they were enacting science concepts at home. As they engaged in this activity, it demystified science concepts and validated home knowledge as the practice of science.

They practiced articulating their knowledge by individually recalling and selecting a memory of home science learning and describing the corresponding science concept. This activity served to diminish the distance between home and school knowledge. Using pastels or markers, each preservice teacher drew a picture of the science memory they learned from their friends, family, or community. Diego's drawing is a sample of the types of memories student depicted (Figure 1). Diego's drawing is followed by Sumer's

classroom field notes of Assignment 2, which provides examples of the preservice teachers' articulations. 


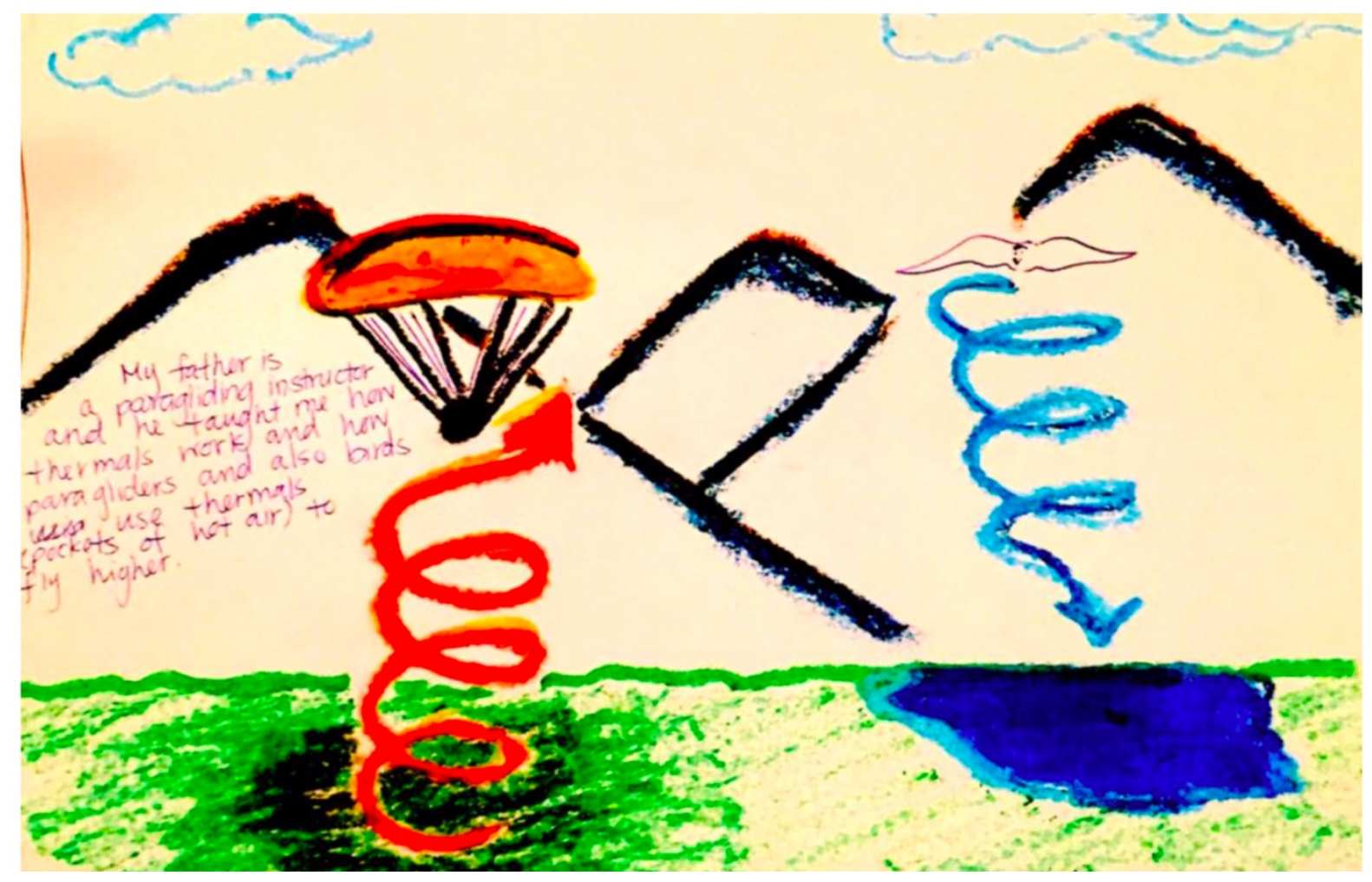

Fig. 1: Diego's accessing \& articulating familial curriculum

Once their drawings were complete, the whole class stood in a circle. Students held their picture and told their science familial curriculum-making stories, and articulated the connections between home and science.

Jenny shared that in school she learned about chicks and eggs. Jenny's teacher showed them the fluffy chicks, and she thought they were cute. She took an egg from her refrigerator and placed it under her pillow to hatch it. Her mom, who had grown up on a farm, saw Jenny's hidden egg and explained that it wasn't possible to grow an egg from the refrigerator because grocery store eggs were not fertilized.

Elaine shared, "My mom taught me the secret to making golden brown egg rolls. The secret she said is to not put too many egg rolls in the pan." A student turned to her and asked, "how is that science?" Elaine replied, "Well, if you put too many [egg rolls] in the pan, the oil temperature gets lower and the egg rolls don't brown-they just get soggy. It's about heat transference. Having too many egg rolls in the pan causes the temperature of the oil to go down."

Students connected in different ways. Jenny and Elaine were able to relate science to everyday life and home chores; they became conscious of every home being a site of science and knowledge production. These stories are complemented by Diego and Will, and captured in Sumer's field texts below:

Diego, he held up his drawing [Figure 1] and explained, "My Dad taught me to fly high by tracking birds." Thermals, he explained, are pockets of hot air along the beach. My Dad is a parasailing instructor and he explained that pockets of hot air rise in heat convection. I learned how to look for birds on the beach, then scan below them [the bird flocks] to look for dark 
patches on the sand and identify where the thermal pockets of hot air were; that's where to parasail. He'd [Dad] say, "follow the birds and they will help you to soar."

Diego's story exemplifies the richness that one familial memory can contain, within it, multilayered lessons beyond science facts. For example, Diego's father skillfully communicated his knowledge of birds, physics, and his aspirational hopes for his son to "soar high." When Diego shared his lesson with our class, he too was teaching the class to "soar high." In communal sharing, familial and ancestral wisdom came forth.

Will shared that he grew up on a tropical island in the South Pacific. His family lived there for generations. As an island youngster, at age 5, he went to the beach with his father. Standing on the shores, his Dad taught him about the tides, how they are formed, and what caused them to rise and recess. His Dad, concerned for the well-being of his young son, wanted him to be safe on the sandy beaches with the ever-changing tides. For Will's Dad, such knowledge was important for survival.

After the last student shared, we stood in awe at the rich science lessons that came from home. Students realized, after sharing and listening to others' stories, how prevalent and rich home science lessons can be. It was powerful to experience the ways family entered Sumer's classroom through stories; moms, dads, aunts, grandmas, grandpas, cousins, and friends all came into the class through the sharing of familial science curriculum. Each student brought a part of home with them into Sumer's classroom.

With assistance, all students were able to meet the objective of articulating science concepts from home practices, but what made this transformative was that it actively uncovered elements of aspirational capital (Yosso, 2005) in their science stories. At first, students struggled to translate the everyday home learning into the scientific abstract terms. Then, science was elevated in their stories beyond head knowledge by the hopes and love of their families, which is aspirational capital; it was a revealing of the heart. To share and be seen by their classmates in this way was a powerful experience, and was the place of learning. They took steps towards crossing the border of acceptable science and meaning making, when they made those home connections.

\section{Collective Meaning Making as a Key Component of Border Crossing}

An effective tool to facilitate science and familial connections was collaboration. Peer dialogue and whole-class sharing aided in the recalling and articulating. As preservice teachers spent time in discussion, thinking together, and sharing their memories, they supported and prompted each other to make familial science connections. The pictures they drew and stories they shared were a part of the group learning and teaching process. As they thought and recalled together, sharing in a circle they opened themselves to be seen by others, and they were able to see other households as sites of knowledge. Yosso explains that we come from homes with wealth. Kara commented in her interview:

I really remember ... the people in it [the class] because I remember what they taught about was really interesting. I really remember thinking that because you learn it [familial curriculum] you also learn about your classmates and I really like that, and important stuff not just what they liked, but where they came from. 
Kara shows the value of learning within community and learning science from community. As Judson (2014) explains, teachers "should not do this work alone" (p. 14). It is meant to be collaborative.

This collaboration, however, was not without tension. Some preservice teachers worried about their peers' reactions. Elaine explained, "I'm sharing with the class [about egg rolls] and [I thought] this is something that could be made fun of as a joke, classmates could think oh there's that stereotypical Asian making egg rolls." This tension that Elaine identified could have affected her sharing, but Elaine moved beyond this tension, feeling safe in her group to complete the assignments. Tensions arose in this struggle to embrace home knowledge as valuable and bridging their epistemological worlds. Ultimately, all preservice teachers completed the assignment and, in so doing, were challenged to reconceptualize how they think of science, home, and themselves.

\section{Repositioning Family and Self as Scientist and Teacher}

An outcome of communal learning and making the border explicit, Kara repositioned herself as a science teacher. Kara shared that she had the science knowledge "within me" the whole time:

At first it was really hard because I definitely couldn't automatically make those connections. But once I got to thinking about it, it opened up a whole box of stuff that I had not thought about before. I had it within me, but I hadn't made that connection. Once you make that first connection then there's this, and then there's this, and then there's this...

Kara found within her ancestral and cultural knowledge science concepts. In border crossing between home and science, she was able to lay down her familial curriculum epistemology and ontology and connect it to school science in new ways. As Aikenhead and Elliot (2010) suggested, through this assignment process they built connections and deeper understandings of both home and school.

Will exemplifies the ways epistemology and ontology could be taught through his father's wave lesson. Will was able to understand and explain both worlds and perceptions when he stood teaching in the circle. He showed how his father's indigenous ontological and epistemological perceptions of the world were different from those of Western science, yet, at points, he showed how they aligned. In this moment of sharing, Will provided access to diverse wave concepts through this father's science curriculum. Similarly, Bang et al. (2012) suggested that the science classroom could be a place where we have "multivoiced meanings of core phenomena," a place where we collectively understand the different epistemologies and what they have to offer (p. 308).

Will continued to reflect even after the assignment. As evidence of this, Sumer shares an excerpt from her class reflection:

Will came up to me a week after the initial lesson [Assignment $1 \& 2$ ]. He said he had been thinking about the lessons his father taught him about the waves. He realized his Dad was taught the same lesson by his father, Will's grandfather. The lessons he had learned had been passed generationally. 
This interaction with Will demonstrates that he began to recognize what Kara said earlier, a treasury of knowledge that was "within." Will's recognition of his ancestral knowledge is part of a larger debate of valued knowledge and is an issue that arose for some of the preservice teachers of color. Elaine explained, "I didn't realize the importance of it [familial curriculum] until I came to college . . recently I was thinking that it wasn't until now . . . it's [familial curriculum] not written but there's a lot in it." Kara, Will, and Elaine show the ways that ancestral knowledge is lost, as it is not valued in the same ways within our society nor taught in schools (Yosso, 2005). Yet, in these activities, these preservice teachers began to dismantle the value hierarchy and acknowledged these systems. We collectively replaced and revalued the knowledge we carry within.

\section{Border Crossing Through Teaching}

The concept of border crossing emerged from the findings as preservice teachers worked on using the memories of learning science at home to teach science concepts. The data presented in this section encompasses assignments focused on the last two steps in the four-assignment sequence, Assignments 3 and 4. The data from Assignment 3 included preservice teachers' 10-minute familial curriculum handson science lesson plan, and Assignment 4 included observations of preservice teachers teaching their lesson in different small groups. These assignments were more difficult for preservice teachers because now they have to incorporate the Western science concepts. As a result, some people struggled.

Kara is an example of someone who made the bridge in Assignments 3 and 4. She was able to make a lesson from her familial curriculum, and it was also an example of border crossing, serving as a transformative experience for both herself and her classmates. In this vignette, Sumer shares a class observation of Kara:

Kara was nervous, in fact at the start of the term she said, "I'm not good at science." She was concerned because she felt uncomfortable with being a science teacher. "It's not safe to make mistakes when you're the science teacher," she explained. Now it was time for Kara to be a science teacher of a lesson rooted from her own familial curriculum.

Kara placed her lesson plan on her left side of the large table. From her backpack she removed a rectangular plastic Tupperware. Placing it in the middle of the table, it contained small clumps of boiled taro. She was set to teach her lesson to her small group of Diego and Katherine. Nervous, she touched her typed lesson plan to reassure herself. She scripted out all of her dialogue to ensure that if anxiety crept in, she could reference her plan.

"Today," she began, "we are going to review some of the states of matter, focusing on solids, liquids, and gas, through cooking poi. Poi is an ancient food and common in the Hawaiian Islands, where I'm from." Sumer watched as she taught her small group. They began to collectively mash the taro. The chunks became small clumps as she poured water into the container. Mashing. Mashing. They continued. Kara looked at them and pulled the container closer to her and observed their poi-making skills. She critiqued them, something I've rarely heard her do, "This is too runny and there are clumps." The two students began to mash more. Then she proceeded with her lesson. At the end of her lesson, Kara excitedly said, "Sumer, this was the first time I didn't pick up my paper to teach. I just knew it." 
Reflecting on the classroom vignette above, Kara showed that teaching science from her familial curriculum alleviated some of the stress of teaching science content knowledge, since part of their lesson related to home knowledge. Like her classmates, she was confident in this sharing. Their home identity bumped up against science anxiety. Murphy and colleagues (2012) explained that curriculum making allows individuals to construct themselves differently, cultivating multiple personal identities. Bringing forth familial curriculum from home shed light on these different identities. Kara described these feelings:

It was a lot easier to teach than a lot of other lessons I've taught because I had the knowledge, I didn't have to keep going back and reassuring myself to make sure I wasn't making mistakes. So that part was easier, I already knew [it] inside me.

Kara became the expert teacher, the knower of her family curriculum. She pulled from her familial curriculum as an island native whose family has farmed taro for generations. Kara found a way to bring her ancient traditional and family practices into the science curriculum. She was bringing into the classroom her family's generational knowledge of taro farming, cooking, making poi, and teaching science. She expressed her familial curriculum as she border crossed between the worlds of her familial knowledge of taro and poi, to those of science, reducing her anxiety:

This is science, it was in front of me the whole time, I just never made that connection. [Taro's] a solid, you steam it and it releases gas, and you put liquid in it to make it poi. Once I connected that terminology, it was easy. I knew I had more of it [lesson-content] in me, I didn't have to go out and look for it, researching and looking stuff up.

In her teaching, Kara considered both her familial curriculum making alongside science content. She wrestled with layering familial poi cooking practices, her "first food" alongside using relevant science terminology and concepts. Because Kara was teaching about her familial curriculum, she cared deeply about the accuracy of both.

Preservice teachers like Kara felt more confident about their home knowledge as they taught through their short lessons. It was natural and easy for many of them because the content centered familial knowledge and cultural wealth. Additionally, Diego was able to do both with ease. He explained, "I know it very well, it's been engrained in my memory." Engaged in this transformative curriculum making, we worked to reposition voice, power, and valued epistemological knowledge. In these lessons, preservice teachers worked to embody their emerging identity as "science teacher" and "keeper" of familial knowledge. Thus, this offers a beginning in the longer journey for new teachers.

Different tensions arose in these assignments, some due to the oppressive science practices, some due to difficulty trans-languaging from familial science to Western science. In these assignment activities, preservice teachers faced the hegemony of science in struggling to write lesson plans. For example, Will had difficulty making tides and waves in a water bottle, yet it was still transformative for him. Science emphasizes the gap between home and science because it is abstracted. Will worked to take the lessons he learned on the shores and move them into a wave demonstration in a plastic water bottle. While the abstraction lost some of the knowledge Will was seeking to convey, he persisted. 
Others had contested relationships with family, some of whom triggered racial microaggressions. Diego provided an important insight: "If they don't have a good relationship with their parent(s), it could actually be triggering." Ultimately, Elaine and Anna chose not to use the family memories and choose a different story to teach. Yet, Kara's family, Will's father, Diego's father, and Elaine's mother were still all knowers of familial curriculum and science concepts in our teacher education classroom. Although at times the tensions of family dynamics emerged, we moved forward together and focused on the purpose of transformative curriculum making. We taught science through real and sometimes tenuous relationships, not abstraction.

\section{Discussion}

For culturally diverse preservice teachers in the class, we found these patterns for accessing, articulating, and translating community cultural wealth into short science lessons extremely valuable. Findings point to science being made accessible and relatable through family stories.

Through her deeper understanding of preservice teachers and their families, Sumer cultivated meaningful relationships with them and fostered critical examinations on those whose knowledge counts. Preservice teachers learned to build relational border crossings into science content. It was not just about them making these connections visible; it was also about listening and realizing the prevalence of familial science in the home, and, in so doing, building an expectation through the four assignments that each home was a site of scientific knowledge production. This led to the understanding that science is indeed within the home. Preservice teachers became practiced in making the border visible and crossing that border, which, in turn, positions them to value the home science learning of their future students.

Our research represents a starting point-this transformative curriculum is an opportunity for preservice teachers to learn from self and/or familial curriculum. It gives preservice teachers a structure to begin to inquire. Since preservice teachers are positioned as learners of their own past, they can influence their present teaching and future curriculum making.

Repositioning family knowledge and teaching practices within the preservice teacher classroom was part of the course goal, and findings showed it is a starting point to connect families and push back against assimilation in a science content. In fact, through the four-assignment sequence, preservice teachers' transformative curriculum making allowed us to hear and learn from culturally diverse and ancient voices. Those previously excluded and silenced were able to be present through their descendants; the wisdom they passed on was embodied in their descendants' stories, teaching, and lessons.

We all stand in the circle identifying, articulating, and locating the stories within ourselves and others, preparing one another to border cross between home and school. In so doing, we make the border more porous and redefine the possibilities of science education not as something distant, but as close as home. 


\section{References}

Aikenhead, G. S. (2000). Rekindling traditions: Cross-cultural science \& technology units. http://www.usask.ca/education/ccstu/.

Aikenhead, G. S., \& Elliott, D. (2010). An emerging decolonizing science education in Canada. Canadian Journal of Science, Mathematics and Technology Education, 10, 321-338.

Bang, M., Warren, B., Rosebery, A.S., \& Medin, D. (2012). Desettling expectations in science education. Human Development, 55(5-6), 302-318.

Bourdieu, P., \& Passeron, J. (1977). Reproduction in education, society and culture. Sage.

Clandinin, D. J., \& Connelly, F. M. (1995). Teachers' professional knowledge landscapes. Teachers College Press.

Clandinin, D. J., \& Connelly, F. M. (2000). Narrative inquiry: Experience and story in qualitative research. Jossey Bass.

Clandinin, D. J., Murphy, M. S., \& Huber, J. (2011). Familial curriculum making: Re-shaping the curriculum making of teacher education. International Journal of Early Childhood Education, 17(1), 9-31.

Clegg, T., \& Kolodner, J. (2014). Scientizing and cooking: Helping middle-school learners develop scientific dispositions. Science Education, 98(1), 36-63.

Education Trust-West. (2015). The STEM teacher drought: Cracks and disparities in California's math and science teacher pipeline (September 8). https://west.edtrust.org/resource/the-stem-teacher-drought/Education Trust

Freire, P. (1970). Education for critical consciousness. Continuum.

Freire, P. (1973). Pedagogy of the oppressed. The Seabury Press.

Houle, S. (2015). Familial curriculum making and a home reading program. Journal of Family Diversity in Education, 1(3), 50-66.

Huber, J., Murphy, M. S., \& Clandinin, D. J. (2011). Places of curriculum making: Narrative inquiries into children's lives in motion. Emerald.

Judson, G. (2014). The role of mental imagery in imaginative and ecological teaching.

Canadian Journal of Education, 37(4), 1-17.

Lee, O., \& Fradd, S. H. (1998). Science for all, including students from non-English-language backgrounds. Educational Researcher, 27(4), 12-21.

Lessard, S. (2015). Worlds of curriculum making: Familial curriculum-making worlds and school curriculum-making worlds. Journal of Family Diversity Education, 1(3), 1-16.

Marco-Bujosa, L.M., McNeill, K. L., González-Howard, M., \& Loper, S. (2017). An exploration of teacher learning from an educative reform-oriented curriculum: Case studies of teacher curriculum use. Journal of Research in Science Teaching, 54(2), 141-168.

Miller, E., Januszyk, R., \& Lee, O. (2015). NGSS in action. Science and Children, 53(2), 64. 
McLaughlin, D., \& Calabrese Barton, A. (2013). Preservice teachers' uptake and understanding of funds of knowledge in elementary science. Journal of Science Teacher Education, 24(1), 13-36.

Moll, L. C., Amanti, C., Neff, D., \& Gonzalez, N. (1992). Funds of knowledge for teaching: Using a qualitative approach to connect homes and classrooms. Theory Into Practice, 31(2), 132-141.

Murphy, M., Huber, J., \& Clandinin, D. (2012). Narrative inquiry into two worlds of curriculum making. LEARNing Landscapes, 5(2), 219-235.

https://www.learninglandscapes.ca/index.php/learnland/article/view/Narrative-Inquiry-IntoTwo-Worldsof-Curriculum-Making

Oakes, J., Lipton, M., Anderson, L., \& Stillman, J. (2013). Teaching to change the world. Paradigm.

Patton, M. Q. (2002). Qualitative research and evaluation methods. Sage.

Rosiek, J., \& Clandinin, D. J. (2015). Curriculum and teacher development. In D. Wyse, L. Hayward \& J. Pandya (Eds.), Sage handbook of curriculum, curriculum, pedagogy, and assessment (pp. 293-308). Sage.

Santau, A. O., \& Ritter, J. K. (2013). What to teach and how to teach it: Elementary teachers' views on teaching inquiry-based, interdisciplinary science and social studies in urban settings. The New Educator, 9(4), 255-286.

Seiki, S. (2016). Transformative curriculum making: A teacher educator's counterstory. Curriculum and Teaching Dialogue Journal, 18(2), 11-24.

Seiki, S. (2017). Urban ocean ecosystems: Changing elementary science teaching. Ubiquity: The Journal of Literature, Literacy, and the Arts, 4(1), 19-31.

Tsurusaki, B. K., Calabrese Barton, A., Tan, E., Koch, P., \& Contento, I. (2013). Using transformative boundary objects to create critical engagement in science: A case study. Science Education, 97(1), 1-31.

Yosso, T. J. (2005). Whose culture has capital? A critical race theory discussion of community cultural wealth, Race Ethnicity and Education, 8(1), 69-91. 


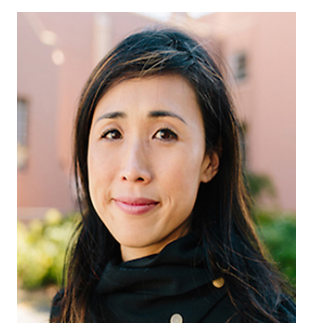

Sumer Seiki is an Assistant Dean, Director of Teacher Education at the University of California, Riverside. She uses narrative research to push the boundaries of the diverse disciplines of science education, ethnic studies, and art. As an interdisciplinary scholar, she interrogates science access through a critical ethnic studies lens, as well as uses scientific knowledge, like that of ecosystem dynamics and functions, to interrogate ethnic studies and art. She seeks to create multi-voiced collective knowledge across different epistemologies.

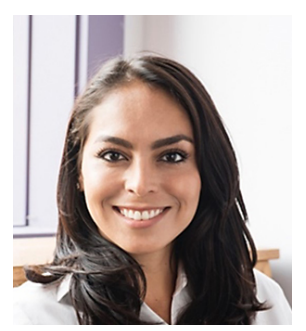

Daniela Domínguez is an Assistant Professor in the Counseling Psychology Department at the University of San Francisco, where she coordinates the Marriage and Family Therapy Program at the Santa Rosa Campus. As a licensed psychologist and clinical counselor, Dr. Domínguez works in the areas of equity, diversity, and inclusion matters. Previously, her program of research has focused on understanding how immigrants cope with risks, threats, demands, and stress and use specific strategies to draw upon resiliencies to achieve positive health.

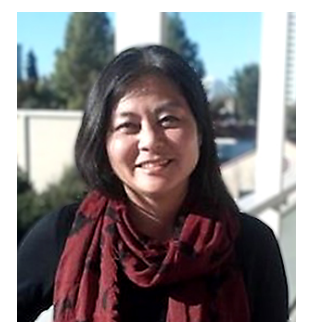

Jolynn Asato is a Lecturer in the Teacher Education Department at San José State University where she teaches literacy methods, social studies methods, and teacher action research. Her areas of expertise are in language, literacy, culturally sustaining practices, and critical educational theory. 